\title{
Ketahanan Pangan Rumah Tangga Kota Surakarta Di Masa Pandemi Covid-19
}

\author{
Wahyu Adhi Saputro ${ }^{1}$, Aris Prio Agus Santoso' ${ }^{2}$ Dhea Ayu Resky Amalia ${ }^{3}$ \\ ${ }^{1,3}$ Program Studi Agribisnis, Fakultas Sains dan Teknologi, Universitas Duta Bangsa Surakarta \\ ${ }^{2}$ Program Studi Hukum, Fakultas Hukum dan Bisnis, Universitas Duta Bangsa Surakarta \\ wahyuadhi@udb.ac.id ${ }^{1}$, arisprio_santoso@udb.ac.id ${ }^{2}$,ayudhea@gmail.com3
}

\begin{abstract}
ABSTRAK
Pangan merupakan kebutuhan essensial bagi manusia. Ketersediaan pangan dan gizi yang cukup menjadi hal yang penting dilakukan sebagai upaya pemenuhan pangan. Peningkatan ketersediaan tersebut nantinya akan berpengaruh terhadap indikator nilai ketahanan pangan. Nilai indikator pangan secara makro mungkin cukup namun bukan berarti di tingkat rumah tangga nilai tersebut juga akan baik. Hal tersebut tidak menjamin bahwa sebuah wilayah dengan akses pangan yang cukup dapat menunjukkan nilai ketahanan pangan yang cukup pula. Kondisi tersebut terjadi di beberapa wilayah di Indonesia dan dimungkinkan juga di Kota Surakarta terutama di masa pandemi seperti sekarang ini. Tujuan dari penelitian ini adalah untuk mengetahui nilai ketahanan pangan masyarakat Kota Surakarta pada saat pandemi covid-19. Data yang digunakan merupakan data primer yang diambil melalui wawancara secara langsung dengan sampel masyarakat Kota Surakarta sebanyak 30 orang. Analisis data yang digunakan dalam penelitian ini adalah klasifikasi silang ketahanan pangan menurut Jonnson and Toole. Berdasarkan hasil penelitian diperoleh bahwa sebagian besar rumah tangga masyarakat Kota Surakarta berada pada kategori tahan pangan.
\end{abstract}

\section{Kata Kunci: Ketahanan Pangan, Pangan, Rumah Tangga}

\section{I.Pendahuluan (Introduction)}

Mempertahankan keberlangsungan hidup merupakan salah satu upaya yang dilakukan oleh manusia dengan mengkonsumsi pangan. Dengan begitu pangan menjadi komponen essensial yang dibutuhkan oleh manusia. Akan tetapi antara saty individu dengan yang lainnya tentunya membutuhkan kecukupan pangan yang berbeda levelnya. Hal tersebut juga berlaku bagi petani yang notabenenya adalah produsen pangan sehingga pemenuhan kebutuhan pangan bagi petani merupakan hak asasi yang sama. Individu dalam memperoleh pangan selain menjadikannya sebagai kebutuhan pokok juga diperlukan sebagai nutrisi bagi pemenuhan individu tersebut untuk terus tumbuh dan berkembang. Dengan begitu pangan yang memenuhi aspek layak dan gizi cukup menjadi penting. Pangan yang cukup bagi masyarakat merupakan pilar pembangunan yang ditunjukkan pada nilai ketahanan pangan wilayah tersebut. Hal tersebut dikarenakan ketahanan pangan yang baik akan membawa pembangunan ekonomi yang baik pula. Akan tetapi Indonesia selaku negara agraris juga masih memiliki permasalahan kompleks khususnya mengenai pangan (Saputro dkk, 2020). Aspek pangan yang terjaga nantinya juga akan berdampak pada aspek kesehatan. Tentunya semua hal tersebut dapat terpenuhi jika asupan gizi diimbangi dengan pola hidup yang sehat (Saputro dan Fidayani, 2020).

Indonesia memiliki angka ketahanan yang menurun dalam tahun 2011 hingga tahun 2013. Hal tersebut dapat dilihat dari indikator konsumsi energi per kapita per hari yang menurun 97 kal pada tahun 2011 hingga tahun 2012 dan kembali menurun sebanyak 10 kal pada tahun 2013 (BPS, 2013). Indikator tersebut menjadikan ketahanan pangan di Indonesia yang semakin terancam. Ketahanan pangan yang menurun tersebut juga menyebabkan Indonesia mengimpor pangan untuk pemenuhan kebutuhan masyarakatnya. Penduduk yang semakin bertambah namun tidak diimbangi dengan penambahan hasil pangan menyebabkan terjadinya kerawanan pangan di waktu mendatang. Ancaman 
tersebut harus segera diselesaikan terutama masalah mengenai lahan dan tersedianya pangan. Permasalahan mengenai ketahanan pangan dapat dirumuskan ke dalam dua aspek yaitu persaingan permintaan produk pangan dan bahan baku dan dinamika selera konsumen yang berubah (Suryana, 2014).

Indikator ketahanan pangan cerminan secara makro bisa saja menunjukkan nilai yang cukup namun tidak serta merta ditingkat rumah tangga indikator tersebut juga berlaku. Bisa saja akses pangan tercukupi namun pendapatan masyarakat yang tidak mampu untuk membelinya begitu juga sebaliknya ketika pendapatan mencukupi namun pangan yang ingin dibeli tidak tersedia (Saputro dan Fidayani, 2020). Rumah tangga berupaya memenuhi kebutuhan pangan keluarganya dengan beberapa cara baik memproduksi sendiri maupun menggunakan pendapatannya untuk membeli produk tersebut (Saputro dkk, 2021). Hal tersebut juga berlaku bagi masyarakat Kota Surakarta terlebih lagi di masa pandemi Covid-19 seperti sekarang ini banyak stok pangan yang cepat habis karena panic buying yang dilakukan oleh beberapa rumah tangga maupun banyaknya pemberhentian kerja yang terjadi bagi masyarakat sehingga masyarakat kesulitan untuk membeli pangan dalam rangka mencukupi kebutuhan pangan keluarganya. Berdasarkan uraian yang telah disebutkan maka penelitian ini bertujuan untuk mengetahui tingkat ketahanan pangan masyarakat Kota Surakarta di masa pandemi Covid-19.

\section{II.Kajian Literatur Terdahulu (Literature Review)}

Ketahanan pangan sering didefinisikan sebagai istilah kecukupan pangan masyarakat di daerah tertentu pada tingkat kapita atau rumah tangga dengan adanya akses pangan yang memadai bagi anggota keluarga. Adanya hal tersebut membuat rumah tangga tersebut dapat bekerja secara maksimal dan hidup layak (Kaplale, 2019). Pangan yang sampai saat ini masih menjadi kebutuhan prioritas menjadikan pembangunan ketahanan pangan harus merata sehingga kemandirian pangan terwujud secara optimal. Selain hal tersebut perlu juga dipertimbangkan mengenai keamanan pangan, mutu dan gizi dalam jumlah yang cukup (Husaini, 2012). Kemandirian pangan dan kedaulatan pangan yang dilakukan di Indonesia tentunya diprakarsai oleh kementerian pertanian dengan langkah strategic pengurangan rumah tangga dengan nilai kerawanan pangan tinggi. Solusi dari adanya masalah tersebut yaitu dengan cara pemanfaatan sumber pangan lokal yang ada di sekitar masyarakat (Atem dkk, 2020). Peningkatan nilai ketahanan pangan harus selaras dengan program pembangunan baik tingkat lokal, regional hingga tingkat nasional. Namun point penting adalah ketersediaan pangan yang berkelanjutan bagi rumah tangga yang ada di Indonesia (Gardjito dan Rauf dalam Lantarsih, dkk., 2011).

Berdasarkan hasil penelitian Saputro dkk (2020) mengenai ketahanan pangan rumah tangga petani di Klaten menyatakan bahwa terdapat keluarga yang masuk ke dalam kategori tahan pangan sebanyak lebih dari 50\% sedangkan 30\% rumah tangga tergolong ke dalam kategori rentan pangan dan sisanya masuk ke dalam kategori kurang dan rawan pangan. Kategori tersebut didasarkan pada klasifikasi silang antara presentasi kecukupan energi dengan pangsa pengeluaran dari masing-masing rumah tangga petani. Indikator tahan pangan dari klasifikasi tersebut jika konsumsi energi lebih dari $80 \%$ diimnbangi dengan pangsa pengeluaran pangan kurang dari $60 \%$.

Hasil penelitian Aggrayni dkk (2015) mengenai ketahanan pangan rumah tangga tani pertanian dan perikanan di Kota Surabaya menyatakan bahwa terdapat 11 rumah tangga petani yang masuk ke dalam kategori tahan pangan sementara itu 20 rumah tangga petani masuk dalam kategori rawan pangan. Kondisi rawan pangan yang dimaksud dibagi lagi ke dalam tiga bagian yaitu rawan pangan tanpa kelaparan, rawan pangan sedang dan rawan pangan berat. Hal tersebut jika dibandingkan dengan rumah tangga perikanan dimana terdapat 6 rumah tangga tahan pangan dan sisanya rawan pangan. Dengan begitu menunjukan bahwa rumah tangga petani masih memiliki nilai ketahanan pangan yang lebih baik daripada rumah tangga petani perikanan hal tersebut dikarenakan petani 
memiliki kelompok urban farming dimana produksi pertanian tersebut dapat dimanfaatkan untuk dikonsumsi.

Berdasarkan hasil penelitian yang dilakukan oleh Haeruddin dkk (2019) mengenai ketahanan pangan di Kota Baubau menyatakan bahwa masyarakat mengonsumis pangan dengan kandungan protein dan kalori yang seimbang dan cenderung normal. Hal tersebut dikarenakan masyarakat memiliki penghasilan dan pendidikan yang cukup tinggi. Dengan begitu kesasdaran mengenai konsumsi protein dan energi dipertimbangkan ketika mengkonsumsi pangan. Pendidikan yang memadai membuat masyarakat sadar bahwa aspek kesehatan penting sehingga pangan yang dikonsumsi harus perhatikan secara benar. Akan tetapi masih terdapat satu permasalahan dimana diversifikasi kurang dilakukan sehingga pemenuhan pangan lebih banyak dari beras walaupun tingkat konsumsi energi perkapitanya sudah cukup. Namun kondisi demikian juga masih ada rumah tangga yang berada pada tingkat defisit walaupun ringan. Jika melihat proposi pengeluaran pangannya maka pengeluaran pangan masih besar pada aspek pangan. Faktor yang mempengaruhi nilai ketahanan masyarakat Kota Baubau adalah banyaknya anggota keluarga, tingkat pendidikan, aset, dan pendapatan. Ketersediaan pangan di daerah ini masih sangatlah cukup dikarenakan distribusi pangan yang baik dari adanya Bulog, toko dagang, rumah pangan kita (RPK) sehingga aksesibilitas terhadap pangan juga tinggi.

\section{III.Metode Penelitian}

Penelitian ini berlokasi di daerah Kota Surakarta. Pemilihan lokasi tersebut dikarenakan lokasi tersebut merupakan salah satu kota terbesar di Jawa Tengah. Penelitian ini menggunakan sampel sejumlah 30 orang masyarakat Kota Surakarta yang diambil secara acak. Pengambilan data menggunakan wawancara secara langsung dengan menggunakan kuesinoner sebagai alat pencari data. Analisis data yang digunakan dalam penelitian ini adalah menggunakan klasifikasi silang Jonnson and Toole. Klasifikasi silang tersebut akan membagi ketahanan pangan rumah tangga menjadi empat bagian yaitu tahan pangan, kurang pangan, rawan pangan dan rentan pangan. Indikator tersebut diperoleh dengan cara mencari data pangsa pengeluaran pangan dan data kecukupan energi yang secara matematis ditunjukkan pada rumus berikut ini (Mulyo et al., 2016):

Keterangan :

\section{$P P P=P P / T P \times 100 \%$}

PPP : Pangsa Pengeluaran Pangan (\%)

PP : Pengeluaran Pangan Rumah Tangga (Rp/tahun)

TP : Total Pengeluaran Rumah Tangga (Rp/tahun)

\section{$\mathrm{PKE}=\mathrm{KED} / 2000 \times 100 \%$}

Keterangan :

PKE : persentase kecukupan energi (\%)

KED : konsumsi energi dan protein per ekuivalen orang dewasa (kkal)

\section{IV.Hasil Dan Pembahasan}

Indikator nilai ketahanan pangan dapat dilihat dari dua nilai. Nilai yang pertama adalah pangsa pengeluaran pangan. Nilai yang kedua adalah kecukupan energi. Data dari kedua nilai tersebut nantinya dimasukkan ke dalam perhitungan klasifikasi silang Jonsson and Toole. Jika sudah dimasukan ke dalam perhitungan klasifikasi silang tersebut maka barulah dapat dilihat rumah tangga mana yang masuk ke dalam kategori tahan pangan maupun yang tidak. Tentunya antara satu rumah tangga dengan rumah tangga yang lain tidak sama bergantung pada tingkat pendapatan total rumah tangga tersebut dan kebutuhan pangan dari rumah tangga tersebut. Kategori rumah tangga yang baik berdasarkan indikator ketahanan pangan adalah ketika konsumsi pangan dan energinya cukup sesuai dengan klasifikasi yang sudah disebutkan. 


\section{Pangsa Pengeluaran Pangan}

Indikator ketahanan pangan yang pertama adalah pangsa pengeluaran pangan dimana angka tersebut merupakan simbol dari kualitas maupun kemanan pangan yang dikonsumsi. Pada dasarnya rumah tangga memiliki pengeluaran baik dari pangan maupun non pangan. Pengeluaran rumah tangga sering didefinisikan sebagai korbanan sejumlah uang bagi rumah tangga dalam rangka pemenuhan kebutuhan hidup. Ketahanan pangan berbanding terbaik dengan pangsa pengeluaran pangan dimana pangsa pengeluaran pangan yang tinggi justru menunjukan nilai ketahanan pangan yang rendah begitu juga sebaliknya. Rumah tangga yang tergolong dalam ketahanan pangan yang baik ketika pangsa pengeluaran pangannya berada pada bawah nilai $60 \%$ dari total pengeluaran rumah tangga tersebut. Berikut ini penjelasan tabel mengenai pangsa pengeluaran pangan rumah tangga masyarakat Kota Surakarta.

Tabel 1. Distribusi Pangsa Pengeluaran Pangan (PPP) Rumah Tangga Masyarakat Kota Surakarta

\begin{tabular}{lcr} 
& \multicolumn{2}{c}{ Rumah Tangga Tani } \\
\cline { 2 - 3 } Pangsa Pengeluaran Pangan & Jumlah & Persentase (\%) \\
\hline Rendah $(<60 \%$ pengeluaran total) & 22 & 73,33 \\
Tinggi ( $\geq 60 \%$ pengeluaran total) & 8 & 26,67 \\
\hline Jumlah & 30 & 100,00 \\
\hline
\end{tabular}

Sumber : Analisis Data Primer 2021

Berdasarkan tabel 1 mengenai distribusi ruma tangga di Kota Surakarta berdasarkan nilai pangsa pengeluaran pangan menunjukkan bahwa sebagian besar rumah tangga telah berada pada kategori tahan pangan. Sebanyak 73,33\% rumah tangga telah meliki nilai pangsa pengeluaran pangan di bawah $60 \%$ sedangkan sisanya pengeluaran pangannya masih tergolong tinggi. Rumah tangga yang pangsa pengeluarannya tinggi biasanya masih memfokuskan pengeluaran pangan yang menjadi prioritasnya. Ketika pangsa pengeluaran rendah maka ketahanan pangan semakin membesar. Rerata masyarakat Kota Surakarta memiliki pengeluaranm rumah tangga sebesar Rp 1.589.500/bulan.

\section{Persentase Kecukupan Energi}

Indikator kedua yang dibutuhkan untuk melakukan perhitungan klasifikasi silang ketahanan pangan adalah mengenai konsumsi energi. Tentunya individu membutuhkan energi ketika melakukan aktivitas baik ringan maupun berat dengan begitu pangan yang dikonsumsi harus mengandung energi yang cukup. Nilai konsumsi energi disimbolkan dalam bentuk kalori rerata per harinya. Perhitungan konsumsi tersebut dilihat dari bahan pangan apa saja yang dikonsumsi oleh rumah tangga tersebut kemudian dibagi dengan jumlah anggota rumah tangga. Konversi nilai tersebut selanjutnya disinkronkan dengan DKBM (Daftar Komposisi Bahan Makanan). Pemenuhan energi tersebut tentunya juga dapat dilihat dari pangan beberapa sumber seperti karbohidrat yang berasal dari umbi, beras dan lainnya. Dengan begitu dapat kita lihat juga sumber pangan utama dari rumah tangga tersebut bersumber darimana saja. Berdasarkan susenas rerata penduduk di Indonesia memiliki sumber pangan tertinggi yang berasal dari konsumsi beras. Untuk lebih jelasnya konsumsi energi rumah tangga masyarakat Kota Surakarta dapat dilihat dari tabel berikut ini: 
Tabel 2. Distribusi Persentase Kecukupan Energi (PKE) Rumah Tangga Masyarakat Kota Surakarta

\begin{tabular}{lcr} 
Persentase Kecukupan Energi & Rumah tangga Tani \\
\cline { 2 - 3 } & Jumlah & Persentase (\%) \\
\hline Kurang (<80\% syarat kecukupan energi) & 10 & 33,33 \\
Cukup (>80\% syarat kecukupan energi) & 20 & 66,67 \\
\hline Jumlah & 30 & 100,00 \\
\hline
\end{tabular}

Sumber : Analisis Data Primer 2021

Berdasarkan tabel di atas dapat diketahui bahwa sebagian besar masyarakat Kota Surakarta berada pada konsumsi energi yang cukup. Sebanyak 20 rumah tangga yang ada di Kota Surakarta memiliki kecukupan energi di atas $80 \%$ sedangkan sisanya sebesar 33,33\% masih kurang dalam pemenuhan energinya. Pemenuhan kebutuhan pangan di Kota Surakarta bersumber pada beberapa pangan seperti beras, ketela, jagung dan bahan pangan lainnya. Masyarakat Kota Surakarta memanglah masih menjadikan beras sebagai komponen pangan utama sehingga langkah diversifikasi juga menjadi hal penting yang harus dilakukan.

\section{Tingkat Ketahanan Pangan Rumah Tangga Tani di Kota Surakarta}

Jika data mengenai indikator ketahanan pangan sudah didapatkan maka kemudian dilakukan perhitungan klasifikasi silang antara pangsa pengeluaran pangan dengan konsumsi energi. Dengan begitu nantinya akan terbentuk empat kategori ketahanan pangan yaitu tahan pangan, rentan pangan, kurang pangan dan rawan pangan. Tentunya rumah tangga dengan pemenuhan pangan yang baik apabila pangsa pengeluaran akan pangannya tidak lebih dari $60 \%$ dan konsumsi energinya mencukupi $80 \%$ berdasarkan ekuivalensi kebutuhan energi orang dewasa. Lebih jelasnya kategori rumah tangga masyarakat Kota Surakarta dalam ketahanan pangan dapat dilihat pada tabel berikut ini:

Tabel 3. Jumlah Rumah Tangga Menurut Tingkat Ketahanan Pangan Jonsson and Toole di Kota Surakarta

\begin{tabular}{lcr}
\hline \multirow{2}{*}{ Tingkat Ketahanan Pangan } & Rumah Tangga Tani & \\
\cline { 2 - 3 } & Jumlah & Persentase (\%) \\
\hline Tahan Pangan & 19 & 63,33 \\
Rentan Pangan & 8 & 26,67 \\
Kurang Pangan & 2 & 6,67 \\
Rawan Pangan & 1 & 3,33 \\
\hline Total & 30 & 100,00 \\
\hline
\end{tabular}

Sumber : Analisis Data Primer 2021

Berdasarkan tabel 3 dapat diketahui bahwa sebagian besar rumah tangga masyarakat Kota Surakarta berada pada tingkat ketahanan pangan yang baik atau dalam kategori tahan pangan. Akan tetapi masih terdapat rumah tangga yang masuk ke dalam kategori rawan pangan. Sementara itu masih terdapat keluarga yang masuk dalam kategori rentan pangan dan kurang pangan sebesar $26,67 \%$ dan 6,67\%. Namun secara keseluruhan rumah tangga masyarakat Kota Surakarta berada pada kategori tahan pangan. 


\section{Permasalahan pangan di Masa Pandemi Covid-19}

Permasalahan pangan di masa pandemi sangatlah kompleks. Berdasakan hasil penelitian masih adanya rumah tangga yang berada pada kondisi tidak tahan pangan karena beberapa hal. Adanya pandemi menyebabkan kondisi panic buying sehingga menyebabkan pangan yang tersuply tidak merata. Adanya hal tersebut berakibat pada harga pangan yang cenderung tidak stabil karena permintaan beberapa bahan pangan yang tinggi khususnya yang berkaitan dengan kesehatan dan imunitas individu. Selain hal tersebut terdapat beberapa rumah tangga yang total pendapatannya menurun dikarenakan pemotongan gaji karena adanya kebijakan work from home sehingga dari waktu kerja yang ada hanya setengah waktu bisa bekerja. Adanya pengurangan total pendapatan rumah tangga tersebut membuat pemenuhan kebutuhan pangannya menjadi berkurang atau prioritas terhadap pangan tinggi dan non pangan diabaikan sehingga membuat rumah tangga tersebut menjadi tidak tahan pangan.

\section{V.Kesimpulan (Conclusions)}

Berdasarkan hasil penelitian dapat diketahui sebanyak 63,33\% masyarakat Kota Surakarta berada pada kategori tahan pangan. Terdapat pula rumah tangga yang berada pada kategori rentan pangan dan kurang pangan dengan persentase sebesar 26,67\% dan 6,67\%. Akan tetapi masih terdapat rumah tangga di Kota Surakarta yang masih tergolong dalam kategori rawan pangan walaupun tidak besar persentasenya. Permasalahan pangan saat pandemi sangatlah kompleks sehingga perlu pengangan khusus dan lebih lanjut. Pemberian bantuan sembako pada masyarakat oleh pemerintah baik pemerintah daerah maupun pusat dirasa memang langkah yang sudah tepat namun harus berkelanjutan. Selain itu pemberian insentif kepada masyarakat untuk tetap produktif di masa pandemi juga menjadi hal yang penting agar total pendapatan rumah tanga tetap stabil sehingga pemenuhan pangan tercukupi.

\section{Ucapan Terima Kasih (Acknowledgements)}

Ucapan Terimakasih Kami Berikan Kepada Deputi Bidang Penguatan Riset dan Pengembangan, Kementerian Pendidikan, Kebudayaan, Riset dan Teknologi Yang Telah Memberikan Hibah Penelitian Dosen Pemula. Penulis juga mengucapkan terimakasih kepada LPPM UNiversitas Duta Bangsa Surakarta yang telah memberikan izin penelitian.

\section{Daftar Pustaka (References)}

Anggrayni, FM. Andrias, DR. Andriani, M. (2015). Ketahanan Pangan Dan Coping Strategy Rumah Tangga Urban Farming Pertanian Dan Perikanan Kota Surabaya. Media Gizi Indonesia, 10 (2). $173-178$

Atem. N. N. (2020). Persoalan Kerawanan Pangan pada Masyarakat Miskin di Wilayah Perbatasan Entikong (Indonesia-Malaysia) Kalimantan Barat. Jurnal Surya Masyarakat, 2(2), 94-104.

Badan Pusat Statistik. (2013). Rata-rata konsumsi kalori dan protein per kapita per hari menurut provinsi, 2007-2013. Diakses dari http://www. bps.go.id/linkTabelStatis/view/id/951

Haeruddin. Harimu, la. Basri, SM. Saprin. (2019). Ketahanan Pangan Masyarakat Kota Baubau. Kainawa: Jurnal Pembangunan dan Budaya. 1 (1). 31-44.

Husaini M. (2012). Karakteristik sosial ekonomi rumah tangga dan tingkat ketahanan pangan rumah tangga petani di Kabupaten Barito Kuala. Agrides. 4 (2).

Kaplale, R. (2019). Aksesibilitas Pangan Rumah Tangga Di Desa Manuweri Kecamatan Babar Timur Kabupaten Maluku Barat Daya. AGRILAN : Jurnal Agribisnis Kepulauan. 7 (2). 197-209 
Lantarsih, R., Widodo, S., Darwanto, D. H., Lestari, S. B., \& Paramita, S. (2016). Sistem ketahanan pangan nasional: kontribusi ketersediaan dan konsumsi energi serta optimalisasi distribusi beras. Analisis Kebijakan Pertanian, 9(1), 33-51.

Mulyo, J. H., Sugiyarto, S., \& Widada, A. W. (2016). Ketahanan dan Kemandirian Pangan Rumah Tangga Tani Daerah Marginal Di Kabupaten Bojonegoro. Agro Ekonomi, 26(2), 121. https://doi.org/10.22146/agroekonom i.17265

Saputro, W. A., \& Fidayani, Y. (2020). Analisis Faktor-Faktor Yang Mempengaruhi Angka Kecukupan Energi Rumah Tangga Petani Di Kabupaten Klaten. VIGOR: Jurnal Ilmu Pertanian Tropika dan Subtropika, 5(2), 51 - 55

Saputro, W. A., \& Fidayani, Y. (2020). Faktor-Faktor Yang Mempengaruhi Ketahanan Pangan Rumah Tangga Petani Di Kabupaten Klaten. Agrica (Jurnal Agribisnis Sumatera Utara), 13(2), 115123.

Saputro, W. A., Fidayani, Y., \& Salamah, U. (2020). Ketahanan Pangan Rumah Tangga Petani di Kabupaten Penyangga. Kediri: Lembaga Mutiara Hidup Indonesia.

Saputro, W. A., \& Fidayani, Y. (2020). Ketahanan Pangan Rumah Tangga Petani di Kabupaten Klaten. Jurnal Sosio Agribisnis (JSA), 5(2), 87-93.

Saputro, W.A., Santoso, APA., Salamah, U. (2021). Kemandirian Pangan Rumah Tangga Tani Di Kabupaten Klaten. Seminar Nasional dalam Rangka Dies Natalis ke-45 UNS Tahun 2021. 5 (1). 918-926.

Suryana, A. 2014. Menuju Ketahanan Pangan Indonesia Berkelanjutan 2025: Tantangan Penanganannya. Forum Penelitian Agro Ekonomi 32(2): 123-135. 